\title{
THE INFLUENCE OF TRANSFORMATIONAL AND TRANSACTIONAL LEADERSHIP, AND ALSO MOTIVATION ON EMPLOYEE'S PERFORMANCE
}

\author{
Marlis Nur \\ Economic and Business Faculty, Halu Oleo University of Kendari \\ Arbia Ali \\ Economic and Business Faculty, Halu Oleo University of Kendari \\ Yusuf \\ Economic and Business Faculty, Halu Oleo University of Kendari, yusuf_rauf@rocketmail.com \\ Chamariyah \\ Economic Faculty, Wijaya Putra University of Surabaya
}

\begin{abstract}
This study aims to analyze the effect of transformational and transactional leadership style and also motivation on the performance of employees in the public works agency at Kolaka district. The study was conducted using a survey of 50 civil servants Kolaka district department of public works. The results showed that transformational and transactional leadership style, and also motivation influence the employee's performance.
\end{abstract}

Keywords: Transformational leadership style, Style transactional leadership, Motivation, Employee performance

\section{Abstrak}

Penelitian ini bertujuan untuk menganalisis pengaruh gaya kepemimpinan tranformasional, gaya kepemimpinan transaksional dan motivasi terhadap kinerja pegawai pada dinas pekerjaan umum kabupaten kolaka. Penelitian dilakukan dengan menggunakan metode survei pada 50 orang pegawai negeri sipil dinas pekerjaan umum kabupaten kolaka. Hasil penelitian menunjukkan bahwa gaya kepemimpinan transformasional, gaya kepemimpinan transaksional serta motivasi berpengaruh terhadap kinerja pegawai.

Kata kunci: Gaya kepemimpinan Transformasional, Gaya kepemimpinan Transaksional, Motivasi, Kinerja pegawai

JEL Classification: M54

\section{Research Background}

The success of a leader in creating effective performance depends on the leadership style. The effective work performance would be able to achieve by adapting leadership with the situation. The effective leadership depends on several factors. There is no single effective leadership that can be applied in all kinds of situation or circumstances. Situation or circumstances are the ones that influence the leadership, for instance, the condition of the followers, group assignments, organization norms and organization environment.

Those factors determine the leadership style which should be used so it would be effective, because there are no better ways of influencing the behavior of others than the leadership. The type of leadership which should be used depends on the level of readiness of the people. A leader is able to improve the level of effectiveness in leadership by changing the situation, so it would be suitable with his/her leadership. There are 3 factors influence the effectiveness of leadership: (a) the quality of relationship between a leader and the subordinates, (b) the power of a leader in that position, (c) the level in the line of duty. If those three factors exist in leadership, then the leadership would be effective. Leadership cannot be called good or bad, but it can be considered 
effective in one particular circumstance and ineffective in another circumstance (Fidler and Chemers, 1984, in Wirawan, 2002:55)

The experts (such as Bass, 1990; Berry and Houston, 1993; Burn in Pawar and Eastman, 1997; Eisenbach et al., 1999; Keller, 1992) reveal the two leadership styles in organization; transformational and transactional leadership styles. One of the theories, which emphasizes changing and the most comprehensive in terms of leadership, is the theory of transformational and transactional leadership (Bass, 1990). The beginning idea of transformational and transactional leadership was developed by James MacFregor Gurns, who applied them in politics context. Then, the idea is improved and introduced in the context of organization by Bernard Bass (Berry and Houston, 1993). Burn (in Pawar and Eastman, 1997) revealed that transformational and transactional leadership can be clearly separated and both of them are contradictory. Transformational and transactional leadership are very important and are needed in every organization.

The influence of leadership style on the improvement of employees' performance has been proved by Sarira (2009) by stating that the suitable leadership would gain positive response from the employees so their performance would be increased. However, Handoyo et al., (2015) found that although the simultaneous transformational and transactional leadership simultaneously influence employees' performance, the test result partially shows that both transformational and transactional leadership are not able to increase employees' performance.

Work motivation is also an important factor in increasing employees' performance, because high work motivation would be accompanied by the increasing of employees' performance (Rafiuddi, 2009; Handoyo et al., 2015)

\subsection{Literature Review}

According to Stogdiil (Stonner, 1996:161), leadership is a process of leading and influencing activity which are related to the work of the member of the group. Meanwhile, according to Ermaya (1999:11), leadership is the ability of a leader to control, lead, affecting mind, feeling or behavior of others in order to achieve goal so the individuals' performance could be increased. Based on those definitions mentioned above, it can be interpreted that leadership is the ability of individuals in guiding, affecting and controlling others or subordinates in order to do the work willingly and with consciousness in achieving certain goal.

Podsakoff et al., (1996) explained that transformational leadership style is the determinant factor which affecting employees' attitude, perception and behavior. According to Bycio et al., (1995) and Koh et al., (1995), transactional is leadership style in which a leader focuses attention on interpersonal transaction between a leader and employees involving the relationship of exchange. The exchange is based on the deal about the target classification, working standard, work assignment and appreciation.

The research of Juk Haedir Sarira (2009) stated that leadership style has significant positive influence on performance. Samsi (2006) stated that the commitment of a leader directly or indirectly has significant positive influence on the employees' performance.

Reksohadiprodjo and Handoko (1996:256) explained that motivation is the individual personal condition which encourages individual to do certain activities in order to achieve the goal. In fact, motivation is the strength which can stimulate or encourage with work spirit toward the employees, so it can change the individual's behaviour and it can be used to increase the performance as it is expected by the organisation. High work motivation, according to Rafiuddin (2009) and Handoyo et al., (2015) will drive the increase of employees' performance.

Based on those things mentioned above, the hypothesis of this research would be:

H1:Transformational, transactional leadership style and work motivation have significant positive influence on employees' performance.

H2:Transformation leadership style has significant positive influence on employees' performance. 
H3:Transactional leadership style has significant positive influence on employees' performance. H4:Work motivation has significant positive influence on employees' performance.

\section{Research Method}

This research was implemented using the approach of survey method with 50 civil employees in department of Public Work Service in Kolaka district. The data analysis in this research used the analysis of multiple linear regressions.

\section{Result and Discussion}

The summary of multiple linear regressions analysis in this research can be seen in the following table below.

Table 1. The analysis result of coefficient value

\begin{tabular}{|c|c|c|c|c|c|c|c|c|}
\hline \multirow[t]{2}{*}{ Model } & \multicolumn{2}{|c|}{$\begin{array}{c}\text { Unstandardized } \\
\text { Coefficients }\end{array}$} & \multirow{2}{*}{$\begin{array}{c}\begin{array}{c}\text { Standardize } \\
\text { d } \\
\text { Coefficients }\end{array} \\
\text { Beta }\end{array}$} & \multirow[t]{2}{*}{$\mathbf{t}$} & \multirow[t]{2}{*}{ Sig. } & \multicolumn{3}{|c|}{ Correlations } \\
\hline & B & $\begin{array}{l}\text { Std. } \\
\text { Error }\end{array}$ & & & & $\begin{array}{l}\text { Zero- } \\
\text { order }\end{array}$ & Partial & Part \\
\hline (Constant) & 0,179 & 0,199 & & 0,898 & 0,374 & & & \\
\hline $\begin{array}{l}\text { Transformational } \\
\text { leadership style }\end{array}$ & 0,258 & 0,124 & 0,262 & 2,084 & 0,043 & 0,887 & 0,294 & 0,109 \\
\hline $\begin{array}{l}\text { Transactional } \\
\text { leadership style }\end{array}$ & 0,492 & 0,108 & 0,492 & 4,568 & 0,000 & 0,904 & 0,559 & 0,239 \\
\hline Work Motivation & 0,216 & 0,096 & 0,232 & 2,240 & 0,030 & 0,848 & 0,314 & 0,117 \\
\hline
\end{tabular}

Based on the analysis result of multiple linear regressions in Table 1, it was found that regression equation produced in this research is:

$$
Y=0,179+0,258 X_{1}+0,495 X_{2}+0,216 X_{3}
$$

Referring to Table 1 and the equation above, it can be interpreted that:

1. Constant (a) has positive value and it shows there is influence from other variables outside of the investigated variables in this research.

2. The regression coefficient value for the variable of transformational leadership style $\left(\mathrm{X}_{1}\right)$ is 0.258 and it shows that there is positive influence and in the same direction as the variable of transformational leadership style $\left(\mathrm{X}_{1}\right)$ toward the variable of employees' performance $(\mathrm{Y})$.

3. The regression coefficient value for the variable of transactional leadership style $\left(\mathrm{X}_{2}\right)$ is 0.492 and it shows that there is positive influence and in the same direction as the variable of transactional leadership style $\left(\mathrm{X}_{2}\right)$ toward the variable of employees' performance $(\mathrm{Y})$.

4. The regression coefficient value for the variable of work motivation $\left(\mathrm{X}_{3}\right)$ is 0.216 and it shows the positive influence and in the same direction as the variable of work discipline $\left(\mathrm{X}_{3}\right)$ toward the variable of employees' performance (Y).

The correlation between the variable of transformational, transactional leadership style and work motivation with employees' performance has the value of multiple R. Meanwhile, the contribution value of 3 independent variables toward the dependent variable and towards the known dependent variable of R-square value can be seen in the following table. 
Table 2. R Multiple value, R-Squarem and Error standard

\begin{tabular}{ccccc}
\hline Model & $\mathbf{R}$ & R Square & $\begin{array}{c}\text { Adjusted R } \\
\text { Square }\end{array}$ & $\begin{array}{c}\text { Std. Error of } \\
\text { the Estimate }\end{array}$ \\
\hline 1 & $0.935^{\mathrm{a}}$ & 0.874 & 0.865 & 0.35709 \\
\hline
\end{tabular}

Based on Table 2, $\mathrm{R}$ multiple value is 0.935 or $93.5 \%$ shows that the correlation between the variables of transformational, transactional leadership style and work motivation with employees' performance is very strong. It is because the result of $\mathrm{R}$ multiple value is closer to 1 or in the position above 0.50 . Furthermore, the determination coefficient value (R2) is 0.874 shows that $87.4 \%$ variation of employees' performance dependent variable is explained by independent variable; transformational, transactional leadership style and work motivation with employees' performance. Moreover, 0.126 or $12.6 \%$ of others is explained by other variables which are not included in the model.

The hypothesis is simultaneously tested based on F calculated value or the probability of (Sig.) F, as it can be seen in the following table.

Tabel 3. F calculated value and Probability of F (Sig.) ANOVA ${ }^{\mathrm{a}}$

\begin{tabular}{llrrrrr}
\hline Model & & Sum of Squares & df & Mean Square & F & Sig. \\
\hline \multirow{3}{*}{1} & Regression & 40.537 & 3 & 13.512 & 105.971 & $0.000^{\mathrm{b}}$ \\
& Residual & 5.865 & 46 & 0.128 & & \\
& Total & 46.403 & 49 & & & \\
\hline
\end{tabular}

a. Dependent Variable: employees' performance

b. Predictors: (Constant), Work Motivation, Transactional, Transformational leadership style.

The test result shows that $\mathrm{F}$ calculated value is 105.971 , with the probability (sig.) of 0.000 . The result of probability level (sig.) is smaller than the assigned level of significant $(\alpha)$ value which is 0.05 . This result shows that transformational, transactional leadership style and work motivation simultaneously has significant influence on employees' performance. Therefore, the hypothesis of the research which stated that transformational, transactional leadership style and work motivation have significant influence on employees' performance can be accepted.

The test result shows that the $\mathrm{t}$ calculated value for the variable of transformational leadership style is 2.084 with probability value (sig.) is 0.043 . The probability value is smaller than the assigned level of significant $(\alpha)$ value which is 0.05 . This result shows that the hypothesis which stated that the variable of transformational leadership style has significant influence on employees' performance can be accepted.

The test result shows that $t$ calculated value for the variable of transactional leadership style is 4.568 with the probability value (sig.) is 0.000 . The result of probability value is smaller than the assigned level of significant $(\alpha)$ value which is 0.05 . This result shows that the hypothesis which stated that the variable of transactional leadership style has significant influence on employees' performance can be accepted.

The test result shows that $t$ calculated value for the variable of work motivation is 2.240 with the probability value (sig.) 0.030 . The result of probability value is smaller than the assigned level of significant $(\alpha)$ value which is 0.05 . This result shows that the hypothesis which stated that the variable of work motivation has significant influence on employees' performance can be accepted.

The discussion about the test result on the influence of transformational, transactional leadership style and work motivation toward employees' performance at public work service department of Kolaka district is:

Based on data analysis, all of transformational, transactional leadership style and work motivation have influence on performance. The finding of this research expands the empirical evidence of Juk Haedir Sarira (2009), Samsi (2006) and Rafiudin (2009) researches, which stated 
that transformational, transactional leadership style and work motivation have influence on employees' performance.

The result of this research shows that the leadership style which always motivates and inspires the employees and also emphasizes working based on the standard, cautious in taking action, will increase the employees' performance. Moreover, employees will be motivated to work well if the leader pay attention to the employees and increase the good relationship with their employees.

Transformational leadership refers to the process of building commitment on organization targets and giving trust on the followers to achieve those targets. In general, transformational leadership has role in changing the culture and organization structure in order to be more consistent with management strategy to achieve organization targets (Bass, 1985).

The result of this research proves that transformational leadership style is able to modify the employees' performance. It means that a charismatic leader, who has direct communication to the subordinates, pays attention, motivates and inspires subordinates, is an important factor to increase the employees' performance. In another word, the more charismatic the leader is the better the employees' performance would be. If the leader often has direct communication to the employees, the employees' performance would be better. Furthermore, if the leader often motivates and inspires the employees, the performance of the employee would also be better.

This finding is supported by the research of Juk Haedir Sarira (2009) which stated that the preferable leadership style by the employees is the important factor to increase the employees' performance because it will boost the employees' satisfaction and they will work hard to give their best.

Based on the variable description of transformational leadership style, leadership indicator always gives motivation and inspiration which is perceived by respondents as dominant indicator to form transformational leadership. It can be explained as it happens in the district of Kolaka, that transformational leadership style is reflected by a leader as always motivates and inspires employees and as a dominant factor in increasing the employees' performance. It is also supported by the respondent's characteristics which are dominated by those employees who work below 10 years and it does not guarantee that they have experience, so they still need motivation and inspiration from the leader.

Transactional leadership allows a leader to motivate and influence subordinates by exchange reward with certain performance. A leader promises to give a reward for those who have achieved a certain target, and a leader is responsive toward personal interest of the subordinates if he is satisfied with the performance (Bass, 1985).

\section{Conclusion}

The finding of this research shows that the transactional leadership style is able to increase the employees' performance in public work service department in Kolaka district. It is shown by the leaders who emphasize the work based on standard and are careful in taking action, and also are active in monitoring subordinates so they will not make mistakes in their action. Those are important factors which influence the employees' performance of public work service department in Kolaka district. The more active the leaders are in monitoring the employees in their work, and also the stricter the leaders are in keeping the standard and the applied principle of cautious, the leaders would be able to increase the employees' performance.

It is supported by the respondents' data characteristics which are based on the employees' level of education in public work service of Kolaka district. More than half of the employees are still in the level of high school and diploma, and they still need guidance and supervision in working based on the standard so that they would not work outside of the assigned standard and procedure. 
Motivation concerns about the way to encourage the working passion of the subordinates, so that they are willing to work hard and giving all the best of their ability and skill to achieve the organization or company's target (Hasibuan, 1999:92). The result of this research shows that high work motivation will increase the employees' performance in public work service in Kolaka district. The finding of this research also proves that out of three needs which motivate the employees to work better, apparently the needs in the link is the strongest indicator in motivating the employees' work in public work service in Kolaka district, especially good relationship with superior / senior and among the colleagues.

It can be explained that employees would work well if the relationship with the superiors/seniors and also colleagues are good, so that if the employees need guidance and report, they would not hesitate or be afraid to come before the superiors/seniors.

This research is conducted with the optimal efforts, however this research still has limitations, such as:

1. The research object is only on the employees of public work service in Kolaka district, so it limits the ability of generalization in the result of this research. Therefore, for the purpose of future research, the research can be conducted in other organization, especially in private sectors.

2. This research is based on the survey data, which only serves the analysis of relationship in the certain period (cross section), so the analysis for different period will be strongly influenced by the changing of environment. Therefore, the further research needs to be conducted and retest the relationship to find out whether the variables in the research have been changing.

\section{References}

Arikunto, suharsimi. 2002. Prosedur Penelitian Suatu Pendekatan Praktek. Edisi Revsi V. Jakarta: Rineka Cipta.

As'ad Moh. 2000. Kepemimpinan efektif dalam Organisasi: Suatu pendekatan Psikologik. Yogyakarta: Liberty.

Bass, B.M. 1990. Bass and Stogdill's Hand Book of Leadership. New York: Free Press

Berry, L.M. and Houston, J.P. 1993. Psychology at Work. An Introduction to Industrial and Organizational Psychology. New York: McGraw-Hill International.

Bycio, P., Hackett, R.D., and Allen, J.S. 1995. Further Assessments of Bass's (1985). Conceptualization of Transactional and Transformational Leadership. Journal of Applied Psychology. 80(4): 468-478.

Burns, James MacGregor. 1998. Transactional and Transformasional Leadership, In Hickman. Gill Robinson, Editor Leading Organizations; Perspectives for a New era, Sage Publications, London.

Bryson, John M. 1995. Strategi Planning for Public and Nono Profit Organizations, A Guide to Strengthening and Sustaining Organizational Achievement. Revisied Edition. SanFrancisco: Josey-Bass Publishers.

Cascio, Wayne. F. 1992. Managing Human Resources: Productivity, Quality of Work Life, Profits. New York: McGraw-Hill, Inc.

Dessler, Gerry. 1992. Manajemen Personalia, Teknik dan Konsep Modern. Jakarta: Erlangga.

Dwiyanto, Agus. 1995. Penilaian Kinerja Organisasi Pelayanan Publi. Makalah disampaikan pada seminar kinerja organisasi Publik. Fisipol UGM, Yogyakarta.

Eisenbach, R., Watson, K., and Pillai, R. 1999. Transformational Leadership in The Context of Organizational Change. Journal of Organizational Change Management. 12(2): 80-88.

Flippo, Edwin. B. 1993. Manajemen Personal (terjemahan). Edisi Keenam. Jilid I. Jakarta: Erlangga. 
French, Wendell. L, And Bell, Ceceil. H. 1995. Organizational Development, Behavioral Science Intervention for Organization Improvement, New Jersey: Prentice Hall International, Inc, Eugewood Cliffs.

Gibson, James. L, Ivancevich, John M, Donnely JR, James H. 1996. Organisasi, Perilaku, Struktur, Proses. Edisi ke delapan. Jakarta: Binapura Aksara.

Handoko. 1998. Kinerja dan Tingkat Emosional. Surabaya: Pranata.

Judge, T.A. 1993. Does Affective Disposition Moderate The Relationship Between Job Satisfaction and Voluntary Turnover?. Journal of Applied Psychology. 78(3): 395-401.

Judge, T.A., and Bono, J.E. 2000. Five-factors Model of Personality and transactional Leadership. Journal of Applied Psychology. 85(5): 751-765.

Judge, T.A., and Locke, E.A. 1993. Effect of Dysfunctional Thought Processes on Subjective Well-Being and Job Satisfaction. Journal of Applied Psychology. 78(3): 475-490.

Judge, T.A., Locke, E.A., Durham, C.C., and Klunger, A.N. 1998. Dispositional Effect on Job and Life Satisfaction: The Role of Core Evaluations. Journal of Applied Psychology. 83 (1): 17-34.

Judge, T.A., and Watanabe, S. 1993. Another Look at The Job Satisfaction-Life Satisfaction Relationship. Journal of Applied Psychology. 78(6): 939-94

Keller, R.T. 1992. Transformational Leadership and The Performance of Research and Development Project Groups. Journal of Management.18(3): 489-501.

Koh, W.L., Steers, R.M., and Terborg, J.R. 1995. The Effect of Transformational Leadership on Teacher Attitudes and Student Performance in Singapore. Journal of Organizational Behavior. 16: 319-333.

Luthans, Fred. 2002. Organizational Behavior. Ninth Edition. New York: McGraw Hill.

Pawar, B.S., and Easman, K.K. 1997. The Nature and Implication of Contextual Influences on Transactional Leadership: A Conceptual Examination. Academy of Management Review. 22(1): 80-109.

Prawirosentono, Suyadi, 1999, Manajemen Sumber daya Manusia, : Kebijkan Kinerja Karyawan ; Kiat membangun Organisasi kompetitif menjelang perdagangan bebas dunia. Edisi Pertama. Yogyakarta: BPEF.

Podsakoff, P., MacKenzie, S.B., and Bommer, W.H. 1996. Transformational Leader Behavior and Substitutes for Leadership as Determinants of Employee Satisfaction, Commitment, Trust, and Organizational Citizenship Behaviors. Journal of Management. 22(2): 259-298.

Robbins, Stephen. P. 1996. Perilaku Organisasi. Jilid I dan II. Edisi Kedelapan. Jakarta: PT. Prenhallindo.

Ruky, Achmad, S. 2002. Sistem Manajemen Kinerja. Jakarta: PT. Gramedia Pustaka Utama.

Samsi A.M. 2006. Disertasi: Pengaruh Komitmen Pimpinan, Komitmen Karyawan, Motivasi Kerja, dan Kepuasan Kerja Karyawan Terhadap Kinerja karyawan Pada PT. Persero Pelabuhan Indonesia III. Program Studi Ilmu Ekonomi, Minat Manajamen Sumber Daya Manusia, Program Pasca Sarjana. Universitas Brawijaya: Malang.

Schultz, Duane. P. \& Schultz, Sydney. E. 1990. Psychology and Industry Today (An Introduction to Industrial and Organizational Psychology-Fifth Edition). New York: Maxwell Mc Millan.

Siagian, Sondang. P. 1994. Patologi Birokrasi. Jakarta: Bumi Aksara.

----------, 2002. Manajemen Sumber Daya Manusai. Jakarta: Bumi Aksara.

, 2002. Teori Pengembangan Organisasi. Jakarta: Bumi Aksara.

Simamora, Henry. 1997. Manajemen Sumber Daya Manusia. Edisi Kedua. Yogyakarta: STIE YKPN.

Singarimbun, Masri and Effendi, Sofian. 1995. Metode Penelitian Survey. Edisi Kedau. Jakarta: LP3ES. 
Siswanto, Bejo. 1987. Manajemen Tenaga Kerja. Jakarta: CV. Haji Masagung.

Soeprihanto, John. 2001. Penilaian Kinerja dan Pengembangan Karyawan. Edisi Pertama. Yogyakarta: BPFE.

Spector, Paul. E. 2000. Industrial and Organizational Psychology: Research and Practice (Second Edition). New York: John Wiley \& Sons, Inc.

Streers, Richard. M. 1985. Efektifitas Organisasi Kaidah Tingkah Laku (Terjemahan). Jakarta: Erlangga.

Stonner, James A.F. Freeman R. Edward, Gilbert JR, Daniel R. 1996. Manajemen. Jilid II. Jakarta: PT. Prenhalindo.

Stumpf N. Mitzi. 2003. Dissertation; The Relationship of perceive Leadership Styles of North Carolina Country Extension Director's to Job Satisfaction of Country Extension Proffesional. Graduates Faculty of North Carolina State University

Sugandha, Dann. 1986. Kepemimpinan Dalam Administrasi. Bandung: Sinar Baru.

Sugiyono. 2002. Metode Penelitian Administrasi. Bandung: CV. Alfabeta. 2003. Statistika untuk Peneltiian. Bandung: CV. Alfabeta.

Sugiyono, Wibowo, Eri. 2002. Statistika Penelitian dan Aplikasi dengan SPSS 10.0 For Windows. Bandung: CV. Alfabeta.

Suradinata, Ermaya. 1995. Psikologi Kepegawaian dan Peran Pemimpin dalam Memotivasi Kerja. Bandung: Ramadan.

-------------. 1997. Pemimpin dan Kepemimpinan Pemerintahan. Jakarta: PT. Gramedia Pustaka. 1999. Pemimpin dan Kepemimpinan. Jakarta: PT. Gramedia Pustaka.

Surakhmad, Winarno. 1998. Dasar dan Teknik Research. Edisi Kedelapan. Bandung: Tarsito.

Suyanto, Bagong. 2002. Kemiskinan dan Kebijakan Pembangunan. Edisi Pertama. Jakarta: Erlangga.

Suyoto. 1997. Postmodernisme dan Masa Depan Peradaban. Jakarta: Aditya Media.

Thoha, Miftah. 1995. Birokrasi Indonesia Dalam Era Globalisasi. Jakarta: Pd. Batang Gadis.

-----------. 1997. Pembinaan Organisasi Proses Diagnosa dan Intervensi. Jakarta: PT. Grafindo Persada.

------------. 2001. Kepemimpinan Dalam Manajemen Suatu Pendekatan Perilaku. Jakarta: PT. Grafindo Persada.

----------. 2001. Perilaku Organisasi Konsep Dasar dan Aplikasinya. Jakarta: PT. Grafindo Persada. 2003. Birokrasi \& Politik di Indonesia. Jakarta: PT. Grafindo Persada.

Suyanto, Endarwati L.M., \& Muhson Ali. 2000. Gaya Kepemimpinan Transformasional Kepada Sekolah Dasar dan Kepuasan Kerja Guru. Universitas Negeri Yogyakarta.

Wahjosumidjo. 1994. Kepemimpinan dan Motivasi. Jakarta: Ghalia Indonesia.

Wijaya IR. 2001. Analisis Statistik dengan Program SPSS 10,0. Bandung: CV. Alfabeta.

Wirawan. 2002. Kapita Selekta Teori Kepemimpinan Pengantar untuk Praktek dan Penelitian. Jakarta: Yayasan Bangun Indonesia \& Uhamka Press.

Wexley, N.K and Yukl, A.G. 2003. Perilaku Organisasi dan Psikologi Personalia. (terjemahan). Edisis Kedua. Jakarta: PT Rineka Cipta.

Yukl, G.A. 1998. Leadership in Organization. Second Edition. Englewood Clifs, New Jersey: Prentice-Hall, Inc. 